\title{
Some Problems in Erik Olin Wright's Theory of Class
}

\author{
Jacek Tittenbrun \\ Faculty of Social Sciences, Adam Mickiewicz University, \\ Wieniawskiego 1, Poznań, Poland \\ E-mail address: jacek@amu.edu.pl
}

\begin{abstract}
Nowadays, Erik Olin Wright's class theory is one of the most influential approaches to social differentiation, although in the mainstream social science the popularity of the so-called EGP class scheme is perhaps greater, Wright's framework has virtually no rivals amongst Marxists and neoMarxists. Both those considerations add to the relevance of the present paper, which is a critical analysis of some of the most salient issues present in the aforementioned framework. Indeed, it turns out that Wright's flaws are more often than not shared by the remaining theorists dealing with social class or stratification. Nomen omen, one of those problems consists in failing to adequately distinguish between those two axes of differentiation. Perhaps the pivotal problem plaguing Wright's framework concerns his flawed understanding of ownership that cannot but reflect on his definition of class and exploitation.
\end{abstract}

Keywords: class; ownership; control; exploitation; Wright

\section{INTRODUCTION}

Wright's class theory involves several problems worthy of a more in-depth analysis. The objective of the paper is thus not a comprehensive presentation of Wright's framework, but, rather, a discussion of some of those theoretical issues it raises. To put it differently, whilst Wright's research is undoubtedly worthy of attention in its own right, our focus is on the problems with Wright's theory of class. What is more, most, if not all of those problems are by no means peculiar to the American theorist, and this wider reference underscores the relevance of the said problems.

\section{CLASS VS. STRATIFICATION}

Wright's writings contain a number of misunderstandings even at a fairly basic level. To begin with, he speaks of "the contrast between unidiniensional and multidimensional perspectives on class and stratification" (Wright 1979).

In point of fact, stratification and class theories cannot be placed at the same footing in the above-mentioned respect. It is only stratification that constitutes a hierarchy, a gradational system whose levels can be ranked according to one, e.g. prestige, income, wealth, or a range of criteria. In this case the above-mentioned distinction makes perfect sense. It does not, 
however, refers to class to which the very notion of multidimensionality seems not applicable, or, to be more precise, it can obviously refer to class analysis in which class concepts are deployed in order to comprehend these or those phenomena, where it naturally can be seen that a class as a social group possesses not only economic, but also political and many other aspects. The same idea must not, though, be transferred into the field of the very procedure of class identification. It would seem that Wright should realise this, as he, after all, locates social classes within the economic structure. As it turns out, however, this is not the case.

The insistence on the non-hierarchical character of class theories cannot be overemphasised since even authors of many books on class theory are apparently not aware of it, as an example of Erik Olin Wright shows. He reckons, namely, that "the diverse definitions of class can be analysed in terms of three nested theoretical dimensions: (1) Whether class is fundamentally understood in gradational or in relational terms; (2) if class is understood in relational terms, whether the pivotal aspect of class relations is seen as located in the market or in production; (3) if class relations are primarily located within production, whether production is analysed above all in terms of the technical division of labor, authority relations, or exploitation. These three theoretical dimensions generate five basic types of definitions of class" () 1979.

We do not dwell here, as this question will be discussed below on Wright's reductionist approach to an issue of economic foundations of class relations which by no means cannot be brought down to the three factors mentioned by him.

\section{ANTAGONISTIC AND NON-ANTAGONISTIC CLASSES}

Wright asks "what it is about the organisation of production that forms the basis for the determination of class", and replies that "Three different ways of understanding the structure of production relations have dominated the analysis of classes within production: production is defined primarily as a system of technical divisions of labor: production is analysed above all as a system of authority relations: and, production, insofar as it determines classes, is seen fundamentally as a system of exploitation" (1979), yet in his answer, strangely enough, the notion of property (not to be conflated with exploitation) is missing and, additionally, classes are situated not only within the system of production but also within other economic substructures.

The concept of ownership is much broader than exploitation. The latter is restricted to the relations between the owners of the means of economic activity and operators of the latter. One should, we contend, use precisely the concept of economic activity rather than simply production, because commerce, transport, finance and services are not production, and yet obviously are part and parcel of the economy. And classes, it should be made clear, are precisely social groups rooted in the economic structure.

The fact that Wright is by means the only one theorist who associates the notion of class with exploitation makes it necessary to look at the matter somewhat more closely.

At the very outset, one common error should be corrected. We have in mind a widely held view according to which In Marx the class structure was conceived of as consisting of two polar classes. Suffice it to mention one example of countless interpretations to the same effect:

"The core process defining class relation, in Marx's class concept, is exploitation; that is, the process by which one class obtains an economic advantage at the expense of another class. In feudalism, the exploitation is 


\begin{abstract}
transparent-the lords of the manor appropriate some of the product of the peasant, or, even more transparently, force the peasant to work for the estate for part of the work week without a wage. In capitalism, the exploitation is hidden, as the worker presumably voluntarily agrees to work for a wage. However, the wage does not reflect the value of the worker's product, which equals the labor power embodied in the [...]. The wage equals the exchange value or the price of labor that will reflect the cost of production of labor, as do other prices. The difference between the wage and the value produced is the source of the capitalist's surplus that generates profits, the end-all of all capitalist activity. The surplus belongs to the worker, and the capitalist therefore be comes rich at the expense of the worker. Clearly, the two classes should have antagonistic interests" (Sorensen, 2000).
\end{abstract}

The entire distinctiveness of Sorensen's formulation, albeit not complete, as his error is shared by many other commentators, is his conflation of the concepts of labour power and labour. This view most likely stems from an interpretation of Marx and Engels' probably most influential work, i.e. "The Communist Manifesto".

We have in mind the following passage of the work:

The history of all hitherto existing society is the history of class struggles. Freeman and slave, patrician and plebian, lord and serf, guild-masterand journeyman, in a word, oppressor and oppressed, stood in constant opposition to one another, carried on an uninterrupted, now hidden, now open fight, a fight that each time ended, either in a revolutionary reconstitution of society at large, or in the common ruin of the contending classes.

In the earlier epochs of history, we find almost everywhere a complicated arrangement of society into various orders, a manifold gradation of social rank. In ancient Rome we have patricians, knights, plebians, slaves; in the Middle Ages, feudal lords, vassals, guild-masters, journeymen, apprentices, serfs; in almost all of these classes, again, subordinate gradations. The modern bourgeois society that has sprouted from the ruins of feudal society has not done away with class antagonisms. It has but established new classes, new conditions of oppression, new forms of struggle in place of the old ones.

Our epoch, the epoch of the bourgeoisie, possesses, however, this distinct feature: it has simplified class antagonisms. Society as a whole is more and more splitting up into two great hostile camps, into two great classes directly facing each other-bourgeoisie and proletariat.

From the serfs of the Middle Ages sprang the chartered burghers of the earliest towns. From these burgesses the first elements of the bourgeoisie were developed.

The discovery of America, the rounding of the Cape, opened up fresh ground for the rising bourgeoisie. The East-Indian and Chinese markets, the colonisation of America, trade with the colonies, the increase in the means of exchange and in commodities generally, gave to commerce, to navigation, to industry, an impulse never before known, and thereby, to the revolutionary element in the tottering feudal society, a rapid development.

The feudal system of industry, in which industrial production was monopolized by closed guilds, now no longer suffices for the growing wants of the new markets. The manufacturing system took its place.

The guild-masters were pushed aside by the manufacturing middle class; division of labor between the different corporate guilds vanished in the face of division of labor in each single workshop.

Meantime, the markets kept ever growing, the demand ever rising. Even manufacturers no longer sufficed. Thereupon, steam and machinery revolutionized industrial production. The 
place of manufacture was taken by the giant, MODERN INDUSTRY; the place of the industrial middle class by industrial millionaires, the leaders of the whole industrial armies, the modern bourgeois.

While it should be emphasised that even the above famous sentences involve a more complex view of the societal class structure than is commonly thought, let us, for the sake of simplification, accept that this commonly held view referred to above contains a grain of truth. Such an interpretation, however, abstracts from the primarily political and ideological, as distinct from scientific, nature of the document under consideration. Even leaving this circumstance aside, though, the above-mentioned view is extremely difficult to reconcile with e.g. historical writings of Marx. In „18th Brumaire of Louis Bonaparte” he writes, for example, about ,aristocracy of finance, the industrial bourgeoisie, the middle class, the petty bourgeoisie". Thus, according to this statement the bourgeois class should be further subdivided. Nevertheless, there is no denying that Marx did not leave any systematic definition of class.

The relevant, nomen omen last chapter of „Capital” (its third volume) is, as is wellknown, similar to Schubert's famous symphony. Still, Marx's claims give rich material for thought. Consider this:

The owners merely of labour-power, owners of capital, and land-owners, whose respective sources of income are wages, profit and ground-rent, in other words, wagelabourers, capitalists and land-owners, constitute then three big classes of modern society based upon the capitalist mode of production.

In England, modern society is indisputably most highly and classically developed in economic structure. Nevertheless, even here the stratification of classes does not appear in its pure form. Middle and intermediate strata even here obliterate lines of demarcation everywhere (although incomparably less in rural districts than in the cities). However, this is immaterial for our analysis. We have seen that the continual tendency and law of development of the capitalist mode of production is more and more to divorce the means of production from labour, and more and more to concentrate the scattered means of production into large groups, thereby transforming labour into wage-labour and the means of production into capital. And to this tendency, on the other hand, corresponds the independent separation of landed property from capital and labour, or the transformation of all landed property into the form of landed property corresponding to the capitalist mode of production.

The first question to be answered is this: What constitutes a class? - and the reply to this follows naturally from the reply to another question, namely: What makes wagelabourers, capitalists and landlords constitute the three great social classes?

At first glance - the identity of revenues and sources of revenue. There are three great social groups whose members, the individuals forming them, live on wages, profit and ground-rent respectively, on the realisation of their labour-power, their capital, and their landed property. However, from this standpoint, physicians and officials, e.g., would also constitute two classes, for they belong to two distinct social groups, the members of each of these groups receiving their revenue from one and the same source. The same would also be true of the infinite fragmentation of interest and rank into which the division of social labour splits labourers as well as capitalists and landlords-the latter, e.g., into owners of vineyards, farm owners, owners of forests, mine owners and owners of fisheries. (Here the manuscript breaks off). 
Let us, however, put ourselves in Marx's shoes and attempt to answer the question which he put to himself. In our view, there can be any doubt that the classes distinguished by the author of „capital” are grounded in economically understood property relations.

Let us, however, verify our interpretation on one of Marx's most prominent followers, who, as opposed to his master, left the precise definition of class, by the way, cited also by Wright. We are speaking, naturally, about Vladimir Lenin according to whom „"Classes are large groups of people which differ from each other by the place they occupy in a historically determined system of social production, by their relation (in most cases fixed and formulated in law) to the means of production, by their role in the social organisation of labour and, consequently, by the dimensions and method of acquiring the share of social wealth of which they dispose. Classes are groups of people one of which can appropriate the labour of another owing to the different places they occupy in a definite system of social economy" (1947: 4921).

Again, much like as in the case of „The Communist Manifesto”, the concrete shape of Lenin's definition was impacted by the fact that it was formulated in the midst of Russian revolution, and thus the grater body of the text containing it was bound to possess political rather than academic nature. Nevertheless, it contains many valuable ingredients. First and foremost, there can be no denying that for Lenin social classes are grounded in the relations of ownership(which, of course, hide behind otherwise rather ambiguous ${ }^{1}$ term: "the relation to the means of production"), ones not only clearly distinguished from their legal expression, but also including, which is most important, the ownership of the labour power. This clearly follows both from other, historical and socio-economic works by Lenin, but also from the context of the definition under discussion. Namely, Lenin stresses that for the total abolition of classes to happen, it does not suffice to abolish merely private property in the means of production, as he writes:

„It is clear that, in order to achieve the total abolition of classes, not only must the power of the landlord and the capitalist be broken, and their rights of property taken from them, but that EVERY private interest in the means of wealth production must be destroyed. The contrast between hand and brain worker (i.e. the owners of different types of the labour power- note: J. T.) must also be ended".

How important is to acknowledge a class-determining character of ownership of not only the means of economic activity but also labour power is shown by the following, rather odd from our standpoint, statement of E. O. Wright who writes: "Giddens (1973) emphasizes Weber's argument that "market capacity" is defined not simply by the possession of capital or labor power, but also by the possession of market-relevant skills (see also Parkin, 1971: 1823). Giddens defines market capacity as "all forms of relevant attributes which individuals may bring to the bargaining encounter (in the market; p. 103)." He then discusses the specific capacities which shape classes in capitalist society (...) When market capacity is extended explicitly to include skills, then the market definitions of class may closely coincide with definitions based on occupational categories, since skill level is one of the basic ways in which occupations are differentiated within the technical division of labor" (1979).

\footnotetext{
${ }^{1}$ The same applies to the term "production relations" used by some writers in their definitions of class. Cooperation or the division of labour, comprising what many Marxist scholars term "the forces of production" are also production relations, as indeed are, too, the relations comprising the structure of the means of production.
} 
Both theorists singularly fail to see that economic ownership is not opposed to market skills, market-relevant skills etc. since skills constitute one of the basic dimensions of labour power which on its part is a key object of economic property.

Lenin's definition has more merits, however. The fact, for example, that he uses the term 'social economy' is, of course, fully consistent with the approach of such classics of the sociology of the economy as Max Weber. Even more valuable is Lenin's focus on "the system of social production" as it suggests that classes exist also outside the sphere of production itself, although not outside the bounds of the economy.

We do not, however, dwell on what seems more controversial in Lenin definition, do not ponder whether class exploitation has been conceived by the author as a necessary or merely secondary and contingent element of the concept of class. This is the case, because, whatever Lenin's eventual position was, we reject any attempt at the reduction the notion of the class structure to antagonistic classes. Each class structure, including that of capitalism, includes classes whose status cannot be couched in these bipolar terms. And yet, it is this simplistic reading of Lenin's definition that is by many identified with the position of the whole current to which Lenin subscribed. To take but one example, E. O. Wright, recognised by many as an expert on class, reckons that "The hallmark of Marxist discussions of class is the emphasis on the concept of exploitation" (1979:14).

Since Wright defines himself as a Marxist, it remains a mystery how he is able to reconcile the above-mentioned view with his own observation regarding "simple commodity production (i.e., production organized for the market by independent, self-employed producers who employ no workers) has always existed within capitalist societies. Within simple commodity production, the petty bourgeoisie is defined as having economic ownership and possession of the means of production, but having no control over labor power (since no labor power is employed)".

Apart from rather convoluted attempts to clarify that contradiction in terms of different level of abstraction, which, frankly speaking, explain nothing at all, since the existence of the class in question is not a matter of conception, but of reality. In other words, one cannot hide behind the assertion that one's theory is formulated at so high level of abstraction that it does not capture the autocephalous class, as we, borrowing the term from Weber, prefer to term those self-employed operators of the means of economic activity, since this amounts to the recognition of the theory's failure.

This may suggest that perhaps the source of Wright's problems in this and may be also in other respects lies in his flawed theory of ownership, including the relationship of the concept in question to other terms he makes use of.

\section{LEGAL AND ECONOMIC OWNERSHIP}

The number and intensity of social and political conflicts around ownership in the real world is almost equal to the number of controversies related to the notion of ownership. Arguably, the fundamental line of division runs between legal and economic, or, more precisely, socio-economic approach to property.

From the viewpoint of the latter, criticism towards not so much jurisprudential theory of property as such (which, of course, retains its validity within its proper domain) as its indiscriminate use in positive or empirically grounded, as opposed to normative or dogmatic, realms of discourse can draw on the intellectual tradition represented by Karl Marx, Max Weber, Eugen von Böhm-Bawerk and other members of the Austrian school of political 
economy, who all have in common a tendency to distrust overgeneralized or reified concepts and to step beyond formalistic fetishized legal notions to those relations that form the economic and social background of law.

One example suffices to indicate how much those comments are necessary. In "The Economic Sociology Bulletin" an author of a special essay devoted to property has no doubts that it is "the legal category of property [that] supplies a semantic form that enables individuals and groups to form expectations concerning the extent to which they can take and retain possession, use, consume, and profit from things (Ford 2009:15- emphasis: J. T.)".

As has been implied above, ownership has a dual mode of existence, so to speak; economic ownership (to be defined later) is to be distinguished from legal ownership, which belongs to what Marxists call the superstructure, as opposed to the economic base of society. While the law generally sanctions the economic relations of ownership, the latter rarely correspond to the prevailing legal forms. Public or state ownership has varying economic and sociological contents or meanings depending on its concrete historical context. Compare, for instance, the ancient East, where the state, personified by the king, was the owner of immense land property, artisans' workshops etc. with the modern West with its often quite high degree of public ownership, or with the "socialist" nations of Eastern Europe, where government ownership was dominant.

On the other hand, one and the same economic relation of ownership may find its expression in diverse legal forms. For instance, legal arrangements concerning property in land differed greatly in the former Soviet Union, Czechoslovakia and Eastern Germany, yet real economic relations of ownership were very similar in all those countries. Furthermore, many legal concepts operate at too high a level of abstraction to be suitable for economic (and sociological) analysis.

This applies, among others, to the crucial concept of the „corporation”. The emergence of the joint-stock company as a major method of business organisation involves legal recognition of the corporation itself as the owner of its assets. But economic ownership can be an attribute of only private or ,natural”, as opposed to legal, persons (or their groups). To recognise a corporation as the owner of its capital does not answer any of the following questions, which are relevant for economic or sociological analysis. Does the corporation belong to the body of shareholders as a whole or a portion of them?

What is the corporation's managers" ownership status?

Is economic ownership wielded by the company's employees as well? Does the concept of indirect ownership through employee pension funds apply here? What is the extent of foreign ownership? Etc., etc. Standard jurisprudential thought fails to penetrate beneath this „corporate veil”.

Jansen puts well this inherently fictional nature of the legal concept under consideration.

When the scale of business activities expands, there will be a point where the required capital can no longer be provided by one person. Multiple investors may be needed. With many investors involved, it is no longer practical to involve all of them in daily decision making. Too many commanders would immobilize the organisation. Decision making is therefore delegated to a board of managers, specifically appointed for this task. It is however not likely that investors would entrust managers with their resources if as stockholders, they also risk loosing money not invested in the company should it fail. The solution to this is the concept of limited liability.

Limited liability for stockholders requires the business to become a legal body, with its own legal rights and obligations. The fact that the business now is a legal entity, in the corporate form, leads to the understandable but fundamentally wrong perception of seeing the 
company as an entity with its own goal or purpose. Because of this misguided 'personalization' of the company Rijkman Groenink, former CEO of ABN AMRO, could say that it would not be in the bank's interest if the company were to be split up after a takeover. But whose interest is that? Who is the bank?

Of course, ABN AMRO as a legal entity exists. Its corporate records are registered. But this is merely a legal fiction, a legal front if you will, behind which the interest of various stakeholders are at play. Employees, stockholders and others have their own identifiable and sometimes conflicting interests. The legal entity has no, and can not have interests of its own. The legal entity serves as a nexus for drawing up contacts between those stakeholders involved in the business activities. These stakeholders will try to get favorable terms when negotiating contracts. Ultimately, these contracts determine how the business' revenues and risks are divided between the stakeholders. (2007:2)

The following real-life example tellingly shows what consequences may follow if the concept of corporate legal person is pushed to its extreme:
"Murray Hill is a public relations firm with liberal tendencies. So when the US Supreme Court ruled recently that companies had the same rights as individuals when it came to financing political campaigns, the people at Murray Hill decided to go one further.
They put up the company as a candidate for election. Why not under the newly clarified law, a company for president?
Campaign manager, William Klein, explained to the BBC's Steve Evans".

It is not only with respect to the subject of ownership that jurisprudential analysis is found wanting. The same applies to its object. Property can be not only in physical ,things" such as machines or land, or in incorporeal or intangible objects such as patents, but also in the labor power or, in Max Weber's terms, Arbeitsqualifikationen. More generally, there are many economic property relations that are not taken account of by the law. To own some object is not necessarily to have a legal title to it. The legal approach to Property by focusing on the holder of a legal document containing provisions enforceable through the courts disregards, among other things, a host of illegal relations composing the black or hidden economy. Putting it another way, economic relations of ownership can rest not only on legal provisions but also on informal agreements, social customs or conventions, etc.

So conceived distinction between legal and economic ownership has nothing in common with quite popular in certain quarters conception according to which "Legal ownership is simple enough. It constitutes the various forms of legal title to property in the means of production".

The usual form of such ownership in advanced capitalism is stock ownership.(...) economic ownership is the most complex (...) Bettelheim (1975) defines it as "the power to assign the objects on which it bears (especially the means of production) to specific uses and to dispose of the products obtained through these means of production (p. 58)." Less abstractly, this means control over the flow of resources into production (i.e., investment and accumulation) (Wright 1979:33).

The above-mentioned notion of legal ownership ${ }^{2}$ as something distinct from economic ownership is commonsensical and superficial; to own a legal title to a portion of equity capital

\footnotetext{
${ }^{2}$ A slightly different, but by no means better variant of this confusion is presented by Sorensen who argues that "Marx's class concept therefore acquires a dual dimension of legal ownership and domination, or power, that is seen as an essential element in the Marxist class concept in discussions and reformulations"(2000). The second part of this formulation may well be true, but sorensen's substantive argument is flawed. Domination does not
} 
may or may not express economic ownership of capital, or, to be more specific, real, as opposed to nominal, economic ownership of capital.

There are a number of specific criteria by which to determine whichever is the case.

Firstly, a given shareholding expresses real economic ownership of share capital if it could be transformed into ownership of a factory or other production unit. Secondly, if it yields income permitting its recipient to live without working. In the case of employee shareholders, they are to be classified as owners of capital rather than labour power when:

1) their shareholdings are worth more than than their labour power;

2) their packages of stock are for them more important source of the means of subsistence than their wages.

Thus, as is easy to see, our view as to what is simple and what is complex is rather different from that of Wright.

The same refers to our notion of real ownership mentioned above as well as to the concept of ownership in general. Meanwhile, E. O. Wright, much like some other Marxist writers, contends that capitalist social relations of production can be broken down into three interdependent dimensions or processes:

1) Social relations of control over money capital, i.e., control over the flow of investments and the accumulation process, or alternatively, control over how much is produced and what is produced.

2) Social relations of control over physical capital, i.e., control over the use of the physical means of production, or control over how things are produced.

3) Social relations of authority, i.e., control over supervision and discipline within the labor process.

The first of these is often referred to as "real economic ownership"; the second and third are often grouped together under the rubric "possession".

The term control within each of these dimensions of social relations needs some explanation. As I shall use the term, control does not primarily refer to an aspect of the relationship of people to things, but rather an aspect of the social relations among people. In everyday language, control implies a capacity to make some kind of decision, and thus a capacity to dispose of some kind of resource. A social relation of control thus implies that this capacity is an attribute of a relation. Individuals per se, in these terms, do not "have" control over money capital, physical capital, or labor; that control is lodged in the social relation into which the individual enters. To say that "capitalists" control the means of production, for example, is to say that the social relationship between capital and labor simultaneously confers on the capitalist position the capacity to dispose of the means of production and deprives the working-class position of that capacity. In a sense, the social relation between capital and labor defines a relationship between these positions and things and thus between the incumbents of these positions (individuals) and things.

This distinction between "positions" and "individuals" cannot be overemphasised. It becomes clearest when the actual decision-making process is lodged in a collectivity of positions, so that even in behavioural terms individuals qua individuals are not "making"

enter into the definition of class. The opposite would be true only if domination could be equated with economic ownership which is not the case, or if the notion of class could be brought down to the bipolar model of antagonistic groupings criticised in the body of the text. 
decisions. But even when a single capitalist makes all of the decisions about investments, use of physical capital, deployment of labor, etc.

This way of breaking down class relations has been developed in different ways by a number of European Marxists, in particular, Balibar (1970), Poulantzas (1973a, 1975), and Bettelheim (1975). A related, but rather different treatment can be found in Carchedi (1977). (Wright 1979:24)

Despite Wright's attempts to endow his concept of control with social referent and to point to other its proponents, his view equating, as it does, ownership with decision-making or power over the means of production is erroneous, as it refers to consequences or preconditions of what Berle and Means call beneficial ownership (1969:8), and not to this ownership as such. To argue that ownership consists in either "the power to assign the means of production to given uses or in the power to dispose of the products obtained" (Poulantzas, 1979: 18) is like staging Hamlet without Hamlet. Making decisions determining the use of the object is not the same thing as actually benefiting from that use. It is not the same thing also in the sense that those who exercise control over given assets need not be those who enjoy the fruits of these assets. The above argument applies even more explicitly to Mises, who expressly states that "ownership is the right of disposal" (1936:517).

Similarly Weber argues that, ,it is essential to include the criterion of power of control and disposal (Verfügungsgewalt) in the sociological concept of economic action if for no other reason than that an exchange economy involves a complete network of contractual relationships, each of which originates in a deliberately planned process of acquisition of powers of control and disposal. This, in such an economy, is the principal source of the relation of economic action to the law. But any other type of organisation of economic activities would involve some kind of distribution of powers of control and disposal, however different its underlying principles might look like. The term Verfügungsgewalt, of which Weber makes a great deal of use, is of legal origin, implying legally sanctioned powers of control and disposal. This, of course, has (in Henderson and Parsons', i.e. the translators of „Economy and Society”) opinion no place in a purely economic conceptual scheme but is essential to a sociological treatment of economic systems. It is another way of saying that concretely economic action depends on a system of property relations" (Weber 1947).

That this treatment is mistaken, can be most easily shown on a number of specific exaamples. The circumstance that an executive of a public library makes a decision where concretely, say, Russian literature should be stored, and which room should accumulate English fiction and poetry and so on and so forth does not, to be sure, transform her into an owner of these resources and the building itself. Similarly, while city authorities may take a decision that a definite street must be closed to traffic, does not renders them private owners of the street involved...the list of such illustrations of our point might be multiplied. It should be also pointed out that the question of defining ownership as benefit rather than control or disposal is not merely a semantic issue. That is to say, even if one adopts a convention according to which ownership is control or decision-making after all, this does not alter the fact that property yields economic benefits which must be somehow termed anyway.

In addition, another arbitrary conceptual decision of Wright is to class one relation of the above set as "ownership" and another as "possession". Is the latter an aspect, of economic ownership or a wholly independent relation? You can argue both ways, but the point is that it is not your duty to secure those key concepts' lack of ambiguity. Ironically, Wright does not follow his own theoretical guidelines according to which "Abstractions are thus not merely arbitrary, analytical conventions used to formulate generalizations about the world; they are conceptual tools necessary to construct real explanations of the world" (1979:26). 
The above-mentioned statements of the theorist under consideration necessitate a further point related to the ontology and epistemology of class. What is at issue is an account of classes as "empty places" as Wright and other neo-Marxists like to say, using a formulation proposed by Simmel (1908). For instance, Erik Olin Wright proclaims that "classes Constitute Positions" (1979:21) and explains: "To say that classes constitute 'positions' implies, to use Przeworski's (1977) apt expression, that there are 'empty places' in the social structure which are filled by individuals. The analysis of class must be understood as the analysis primarily of such empty places, and only secondarily of the actual individuals who fill the slots. While questions of social mobility are important in a class analysis, there is a logical priority to understanding the empty places into which individuals are sorted. Poulantzas (1973a) has emphasized this point: "the question of who occupies a given position, i.e., who is, or becomes a bourgeois, proletarian, petty bourgeois, poor peasant, etc., and how and when he does, is subordinate to the first aspect - the reproduction of the actual positions occupied by the social classes (pp. 49-50)". In a parallel way, Sorrenson (1991:72) states: "Classes are 'sets of structural positions".

Wright Must be familiar with Poulantntzas' intellectual background, but for some unknown reasons fails to draw some lessons from it. Poulantzas, just as Balibar, for that matter, belonged to Louis Althusser's school that pursued not only structuralist but also a highly formalistic species of Marxism. To view the class structure as a web of slots to be filled by concrete interchangeable individuals whose characteristics are irrelevant to the former is simplistic. Take any example of a social class, such As one of industrial capitalists, one is not in a position to predict on the basis of this general definition what specific ownership relations they enter; this must be established on a case-by-case-basis. A particular capitalist may be a beneficiary of one or more forms of, in Marx's terms, surplus value (absolute, relative, extra) and gratuitous economic advantages accruing to him or her thanks to the application of machines, science, simple and complex co-operation and so forth.

Wright and Poulantzas' approach is not only anti-empirical in the above sense, it is also extremely static, it does not allow to study class dymamics, as it is difficult to imagine that one could investigate transformations, let alone struggle of "empty places". In addition, the said approach thus revives a perennial antinomy of structure vs. agency.

\section{CONTRADICTORY LOCATIONS OR ARGUMENTS?}

Wright's false, in our view, theory of ownership underlies his misplaced fights against various conceptual straw men, as in the following example:

\footnotetext{
"For the managerial revolution proponents to prove their case, therefore, it is not enough to show that stock is widely dispersed. They must show that real economic ownership is in the hands of nonowning, professional managers, i.e., that they actually control the accumulation process as a whole" (Wright 1979:35).
}

The three processes that comprise capitalist social relations of production do not always perfectly coincide. This fact is the key to our understanding the class position of the social categories that are labeled "middle class" (or more exactly "new middle classes" to distinguish them from the traditional petty bourgeoisie). The new middle classes can be defined as social categories that occupy contradictory locations within class relations. Of course, in a sense all class positions are contradictory, in that class relations are intrinsically antagonistic social relations. 
Wright's statement so far merely confirms, as has been pointed out above, that he subscribes to the view of the class structure as composed of inherently antagonistic groupings, which view has been criticised above. However, he adds that certain "empty places" in the class structure constitute doubly contradictory locations: they represent positions which are torn between the basic contradictory class relations of capitalist society. Rather than use such a cumbersome expression as "contradictory positions within the basic contradictory class relations of capitalist society," I shall for convenience simply refer to these positions as "contradictory class locations."

Three clusters of such contradictory class locations are especially important:

1. Managers and supervisors occupy a contradictory location between the bourgeoisie and the proletariat.

2. Semiautonomous employees who retain relatively high levels of control over their immediate labor process occupy a contradictory location between the working class and the petty bourgeoisie.

Small employers occupy a contradictory location between the bourgeoisie and the petty bourgeoisie.

Freiherr von Muenchausen, famous for his book of incredible adventures, told the readers how he pulled himself out of a swamp by tugging on his own hair. Wright's way of escaping a self-created conceptual trap bears strong resemblance to Muenchausen's trick. "Class structures may (...) differ not simply in terms of the relative magnitudes of contradictory locations, but also in the ambiguous locations that exist at the boundaries of the basic class locations.

The existence of such ambiguous locations indicates the theoretical limits of a purely structural analysis of classes. Classes are not simply slots within a social structure; they are also organised social forces. The decisive question, then, is how these ambiguous class locations (as well as contradictory locations) become formed into classes; this, in turn, depends on class struggle, not just class structure" (Wright 1979:49). This escape hatch is rather awkward, to say the least. The whole point of any class theory worthy its name is to provide a complete map of a given socio-economic dimension of social life, and Wright's admission that there are some "ambiguous locations" which his theory cannot capture means simply that the theory fails (he tries to mask this fact by extending this failure to class theory in general which constitutes an evident abuse on his part).

Resting, as we do, on the theory of socio-economic ownership, we are able to identify the class position of the classes comprising the above-mentioned cluster without a recourse to any such terminological inventions as Wright's "contradictory class locations". He explains his "conception of the middle class" as follows:

1. "Managers and supervisors occupy a contradictory location between the bourgeoisie and the proletariat.

2. Semiautonomous employees who retain relatively high levels of control over their immediate labor process occupy a contradictory location between the working class and the petty bourgeoisie.

3. Small employers occupy a contradictory location between the bourgeoisie and the petty bourgeoisie" (1979: 27). 
Our notions of ownership of capital and labour power allow as precise class identification of those categories as you can get. Wright's term suggest, and rightly so, that a foreman is close to a worker in class terms. Our rendering of this affinity, though, is completely different. Insofar as he or she performs material labour, he or she is subject to capitalist exploitation since his/her labour produces surplus value. On the other hand, more complex and thus higher valued labour power entails a distinct class position. The latter consideration to an even greater extent applies to the mid-level managers. This class division connected to their more complex labour power is, as it turns out, reflected in the managers' awareness, albeit sometimes in not an altogether straightforward manner, as the following example drawn from construction shows:

\begin{abstract}
"You can't really term it [site management] as earning your money. I always think to earn your money you've got to work hard for it. I don't consider this to be work, I don't know if that makes any kind of sense but I think work, I would relate it to physical work you know. This is just the lighter end isn't it, really. You really get paid extortionately for doing no real work, but you're paid for your knowledge aren't you. It's a strange thing to say, but using your brain isn't really working I think" (Thiel 2007).
\end{abstract}

Managers, technicians and engineers pose a serious problem also for other Marxist class theorists. This problem arises, it may be surmised, because for someone who is accustomed to an old scheme of two antagonistic classes it may be ddifficult how to determine the class location of those groups. At first glance, because they are, just as workers, employees, one should classify them as a part of the working class. That classification, it is easy to see, would be over-simplified, overlooking many socio-economic differences between the categories in question. Hence, barring such unsatisfactory solutions as "the new working class", most writers look for other approaches to the issue. For Carchedi (1977), the criterion that divides wage and salary earners into working-class and new-middle-class components is the distinction between what he calls the "function of the collective worker" and the "global function of capital." The former is defined by Carchedi as "the production of use-values within a complex and differentiated labor process"; the latter is defined as "the control and surveillance of the labor process" - a form of control that Carchedi interprets as essential to the expropriation of surplus value and not merely a technical condition of production. Workers and the new middle class are alike in that both are separated from ownership of the means of production; however, the latter are distinguished from the working class by their participation (in varying degrees) in the global function of capital - that is, by their exercise of supervisory authority.

Now this solution cannot be deemed satisfactory either, if only because corporate executives are by no means excluded from ownership of capital; quite the contrary, the upper, but also increasingly middle echelons of the managerial staff own substantial portfolios of stock. On the other hand, it is problematic whether managers can be en bloc considered as contributing nothing to use value of commodities. Should it be the case, we guess, they would not hold their jobs for long.

In Poulantzas' (1975) theory the working class is distinguished from the new middle class (or what he calls the "new petty bourgeoisie") by three criteria. In addition to the basic economic criterion of class position (which he defines as the distinction between productive and unproductive labor), Poulantzas maintains that political and ideological relations also enter into the structural determination of class. By political and ideological relations he means those relations which secure the reproduction of the dominant mode of exploitation. At the 
political level this is accomplished through the relations of supervision and authority within the capitalist enterprise, which Poulantzas, like Carchedi, interprets as involving not just the technical coordination of labor but also the enforcement of capitalist domination over workers.

This places managers and supervisors in an antagonistic relation to the working class. At the ideological level Poulantzas identifies the basic class relation as the division between mental and manual labor, which he claims reinforces the subordination of workers to capital by excluding them from the "secret knowledge" of production. As the bearers of this relation of ideological domination, professionals, technicians, and other mental workers are classified as part of the new petty bourgeoisie along with managers and supervisors.

Poulantzas' terminological choice is, if anything, even worse than "the middle class", or "the new middle class", for that matter. There is very little in common between a forman, or a technologist on the one hand and, say, a watchmaker or any other representative of the broad category of self-employed or, in the terms of socio-economic structuralism(ass the general theoretical framework of the author of the present paper is termed), the autocephalous class. To add insult to injury, there are problems with the specific definition of productive and unproductive, and, similarly, manual and mental labour.

In Wright's (1978a) original theory of contradictory class locations (which has been already mentioned above, but in order to make our review of representative theoretical positions as complete as possible, we venture to repeat certain points) class positions are defined by a combination of three criteria: control over investment capital, control over the physical means of production, and control over labor. Among wage and salary earners, this yields three types of class locations.

The working class is defined as that group which occupies a subordinate position (no control) on all three of these dimensions. Managers and supervisors occupy a contradictory class location in that, like workers, they are excluded from control over investments, but unlike workers they exercise a degree of control over the physical means of production and over the labor of others. "Semi-autonomous workers" (essentially non-supervisory professionals and technicians) occupy a distinct contradictory class location. Like workers they are excluded from control over both investment capital and the labor of others, but unlike workers, they retain a degree of control over their immediate physical means of production and over their own direct activity within the labor process.

Burris offers a much to-the-point summary characterisation of the three theories concerned:

What characterises all of these theories is the tendency for relations of exploitation to be displaced by relations of domination and subordination, at least insofar as the definition of the new middle class is concerned. Weberians such as Parkin (1979) have interpreted this as a tacit admission by contemporary Marxists of the superiority of Weberian theory. Whether or not this conclusion follows, it is certainly true that the increased importance these theorists attach to authority relations does not square easily with some of the traditional arguments for the superiority of Marxist class analysis. For instance, Marxists often criticize Weberian and other non-Marxist conceptions of class for their gradational nature. This, they argue, generates an indeterminate plurality of positions with no meaningful boundaries between classes as discrete social groups. Yet criteria such as the exercise of supervisory authority, control over the physical means of production, or autonomy in the labor process are also matters of degree. Virtually all workers retain some minimal control over their own labor or their immediate instruments of production. At what point then does the level of control become sufficient to exclude them from the working class? 
Second, Marxists often claim as a virtue of their theory that it yields an unambiguous asymmetry of material interests from which one can deduce probable patterns of political opposition. This is arguably true for the concept of exploitation, but it is less clear that relations of domination and subordination entail any necessary asymmetry of interests. A plausible case can perhaps be made that the domination of managers over workers is asymmetrical in this sense. Whether the "semi-autonomy" or "secret knowledge" of nonsupervisory professionals means that their interests are inherently opposed to those of workers lacking such authority is much more questionable.

Finally, $[\ldots]$ to the extent that Marxists integrate relations of domination into their definition of class, it becomes increasingly difficult to defend either the general primacy of economic relations over political and ideological relations or the more specific claim of the primacy of class over nonclass forms of domination. This is especially true when, as is the case in all three theories examined above, differences in authority take precedence over similarities of economic characteristics in defining the boundaries between classes (Burris 2007:81).

Considering the foregoing, it may come as a surprise that Wright criticises the authority-based approach to social differentiation. Wright rightly notes that "authority definitions of class tend to see authority itself as a unidimensional relation of domination /subordination within a given organisation. No systematic theoretical distinctions are made concerning the object of authority. What matters is having authority or power; little is said about how it is used. Conceptions of class in terms of authority relations thus tend to emphasize the form of class relations over the content of those relations.

Finally, because of this formal character of the conception of class, authority definitions generally do not provide a sustained account of why social conflict should be structured around authority relations. Implicitly, one of two arguments is usually made. Either it is assumed that human beings somehow have an intrinsic drive for power for its own sake, and thus the division between the powerful and the powerless intrinsically constitutes the basis for social cleavage; or it is argued that power and authority enable the powerful to appropriate various kinds of resources, and that as a result the powerless will attempt to gain power for instrumental reasons. The evidence for the first of these assumptions is particularly weak. People may have an intrinsic drive to control their own lives, but there is little evidence that most people have a basic need or drive to control other people's lives. In any event, empirically most struggles over power are struggles over the use of power, not simply the fact of power. The second assumption is thus more plausible. But in order for it to provide a sound basis for an explanation of the relationship of authority to social conflict, it is necessary to develop a systematic theory of the relationship between authority and the appropriation of resources. Most discussions of authority lack such an account (1979).

Given the above criticism, it may appear rather unusual that the American sociologist introduces the concept critisised by him to his own definition of class. The explanation of that puzzle lies in Wright's hope that his approach avoids the drawbacks identified above. He states:

"Classes, in these terms, are most pivotally defined by the relations of appropriation of the surplus product and secondarily defined by the relations of control over the technical division of labor and relations of authority" (1979:18). 
However, the above definition is in effect akin to Dahrendorf's conflict approach. Adding authority to exploitation as an additional dimension of class relations does not go beyond the bipolar view of the class structure as composed of antagonistic classes which, however, is untenable; what is more, this new conceptual addition even strengthents this view as relations of authority are inherently hierarchic. In addition, originality of Wright's position is problematic not only owing to its affinity to that adopted by Dahrendorf, but also because Wright $(1979,1985)$ obtains class categories by cross-classifying property with authority in the manner earlier proposed by Ossowski (1963).

Wright's reductionism has been noticed by other writers as well: "By conflating class, structure and exploitation, Wright's class theory becomes circular and self-validating, because no concept of class itself can be applied to test the class effects of the exploitation mechanism.

The view that identifies only two pre-given, well-formed classes under capitalism conflates exploitation with class, the abstract with the concrete, and the provisional with the 'real'. [...] For Marx, while the abstract foundation is posited as the ultimate historical end point of capitalist development, it does not equate to capitalist society at any preceding historical conjuncture. In Marx's discourse, the practical conflation of the abstract and the concrete is predicted only as the eventual outcome of the logic of capital, which generates increasingly extensive and intensive proletarianisation.

[...] Within Marx's work, there are indications of complex counter-tendencies to the prognosis that the logic of capital will uniformly proletarianise the class-in-itself conditions of the immense majority. First, work practices under capitalism develop unevenly, and do not all tend uniformly to the same real-subordination end point. Complex and uneven class effects are implied when some areas of work do not reach this stage while other areas go beyond it. In particular, Marx's analysis in the Grundrisse indicates other tendencies beyond uniform real subordination of the immense majority. Second, a class-struggle perspective that includes labour and capital as active makers of history suggests an uneven process of development involving labour's resistance and capital's counter-movement, which, in turn, implies both a more open-ended capitalist dynamic and further diversification of the circumstances of the wage-earning proletariat." (Nielson 2005).

\section{EXPLOITATION AND ANALYTICAL MARXISM}

The later shift in Wright's position is interpreted by the commentator cited above as stemming from the recognition that the problems associated with incorporating domination into the Marxist conception of class are so great that such efforts should be abandoned. In his latest writings, Wright (1985) has rejected his earlier theory of contradictory class locations and proposed an alternative way of conceptualizing the class position of salaried managers and professionals. As we shall see [...], however, this has resulted merely in the substitution of one form of convergence with Weberian theory for another. [...] It is on the basis of Roemer's work that Erik Olin Wright has sought to reconceptualize the class position of salaried managers and professionals. Wright (1985) now argues that class is exclusively a relationship of exploitation, rather than a complex unity of exploitation and domination relations. The dominant form of exploitation in capitalist society is that based on the private ownership of the means of production, but there are also subsidiary forms of exploitation that derive from the unequal distribution of other productive assets. One such asset is skills especially those whose supply is artificially restricted through credentialist mechanisms. A second is what Wright calls "organisation assets," by which he means control over the 
conditions for the coordination of labor. Within this framework, salaried managers and professionals are distinguished from the working class by their disproportionate share of one or the other (or both) of these subsidiary assets. Such differentials in skill and organisation assets, Wright argues, enable them (via the mechanism of market exchange) to exploit the labor of other workers, even as they themselves are exploit [exploited] by capitalists.

Whether this reconceptualization successfully exorcizes the concept of domination from the Marxist definition of class is an open question, given that by Wright's own admission the "ownership" of "organisation assets" is rather difficult to distinguish from the exercise of hierarchical authority. But even accepting this distinction, it is clear that Wright has closed one door to Weberianism only by opening another: He has eliminated domination from the definition of class only by elevating the importance of market relations. Wright (1985: 107108) defends the Marxist pedigree of his new theory by arguing that Weberians treat market relations from a culturalist standpoint (i.e., in terms of the meaning systems that shape social action), whereas he conceptualizes market relations from a materialist standpoint (i.e., in terms of objective patterns of exploitation that exist independently of the subjective states of actors). Yet the very introduction of such concepts as "skills" and "credentials" into the definition of class produces an inevitable slide toward a culturalist form of analysis. As both Marxists and Weberians have argued, what passes for "skill" in a given society or what is certified by credentials is very much a social construction and therefore dependent upon the subjective states of actors (Bowles and Gintis, 1976; Larson, 1977; Collins, 1979). (Burris 2007:84-85).

Our aim is not a defence of Wright against whom we have quite a lot of reservations, but simply scientific fairness; the fact that in different national context there may be some differences regarding what objective physical and mental abilities are accorded higher or lower ranks on the scale of skills, this does not negate the objective existence of the underlying personality traits; if the latter were not there, any "cultural" or "social construction" could not have possibly taken place.

The above-mentioned modified approach is debatable as well, albeit not necessarily for reasons given by Nielson, according to whom "Wright's conversion to analytical Marxist economist John Roemer's (1982) narrow reading of exploitation reduces his class concept still further. Exploitation is defined purely in terms of 'inequalities in the distribution of productive assets, or what is usually referred to as property relations' (Wright, 1986: 118). Further, Wright accepts Roemer's incredible claim that 'domination within production ... is not a central part of defining class relations ... it is not the actual criterion for class relations' (1986: 119). On this reading, class is reduced to a single distributive criterion derived from a definition of exploitation that is unrelated to power and production)" (2005).

In light of our previous comments, it is certainly not the non-inclusion of domination or power into the definition of class that should be regarded as its most serious shortcoming.

Wright belonged to the so-called September Group of analytical Marxists whose other prominent members were: G. A. Cohen, John Roemer, Jon Elster, Adam Przeworski, Philippe van Parijs , and Robert-Jan van der Veen. Tthe group was characterized, in the words of David Miller, by "clear and rigorous thinking about questions that are usually blanketed by ideological fog"(1986). These high expectations were tied to the employment of techniques drawn from analytical philosophy, rational choice and game theory. Did those resources prove adequate to dispel the said intellectual fog?

In an attempt to derive the essential sources of inequality as an alternative means to define exploitation the critical issue is how to distinguish fundamental from contingent sources of social advantage. Wright (1985) argued that there were three fundamental kinds of 
assets: property, organisation and skill. In all three cases, those without the relevant assets (the property-less, organisational subordinates, and the unskilled) would be better off in relationships where those assets did not exist. Hence they can be said to be in a relationship of exploitation. This allows some kind of a distinction between outcomes generated by exploitative assets, and those caused more contingently. For instance, since someone's good health does not entail another's bad health (and hence that someone in bad health would not necessarily be better off by changing the health of the person in good health), it might be claimed that 'health status' does not constitute an asset in the way that property, skill and organisation do.

This is true, it can be claimed, even though there is a clear association between health and life chances. Health may be a resource, but this is different from the generative powers of relational class 'assets'. [...] However, subsequent reflection has indicated that this distinction proves difficult to operate in practice. The resource of health, to go back to our example above, may not be a zero sum, but it is a relative state. The employment prospects of those in bad health would be improved if those in good health were not in the labour market. All resources therefore have a relational element and can be linked to processes of social closure, so generating forms of inequality.

In this case they cannot be clearly distinguished from assets. And similarly, it is not always clear that the assets delineated by Wright have a direct relational or exploitative logic. Wright (1985) follows the tradition of social closure theory associated with Weber and Collins in defining skill assets as a means of closing entry to occupations, but as he later admits, it is not clear that this directly involves the exploitation of those without such credentials.

There might remain a subtle difference between non-relational resources and relational assets. Relational assets might be said to depend on a particular configuration of social relationships between those benefiting and those disadvantaged, leading to the possibility of direct contestation between the parties themselves over the terms of the relationship. Nonrelational resources, however, might not be dependent on this kind of direct relationship where those without such resources are not likely to call the resource itself into question. The unhealthy are unlikely to demand the end of good health, for instance.

Although this distinction may be tenable in principle, it also does not appear very robust in application. Consider the distinction, along these lines, between the resource of being able to drive, and the asset of being a right-hander. In contemporary capitalism, knowing how to drive is a significant resource: one is more likely to have job opportunities and access to various leisure and social activities if one can drive. However, there is no reason, in principle, why everyone could not learn to drive. This might appear different from the issue of right and left-handedness, which more directly sets one group against another (left-handers can only with great difficulty become right-handers). It is known that left-handers have a higher mortality rate than right-handers, and this association can probably be explained by the difficulties of left-handers in dealing with right-handed 'technologies'. However, despite this being due to the operation of relational assets, it is not clear that any differences of sociological importance flow from this: there are no signs that left-handers are likely to call their relationship with right-handers into any more question than non-drivers do compared to drivers.

In general then, the problem of using game theoretical logic is that whilst assets can in principle be distinguished from resources it is difficult to see this as a very meaningful distinction for explaining outcomes of sociological importance, whether these be life chances or social action. 
In practice both terms point to the way that advantages of any kind can allow positional gains by those who are advantaged, and it proves difficult to distinguish contingent sources of advantage from more fundamental ones.

The number and range of assets can multiply with little check, leading to a kind of descriptive pluralist account of social inequality (see further Goldthorpe's 2000b comments on how Sorensen's theory of exploitation based on rents permits this proliferation). These observations indicate, in a nutshell, the problems faced by Marxists once they abandon the labour theory of value: it seems difficult to find any axis on which to define advantage which does not permit the possibility of massively proliferating resources and hence axes of inequality.

This is one reason why in practice, most neo-Marxists have sought to put Pandora firmly back in her box ${ }^{3}$ by deciding to restrict interest to assets whose existence can be legitimated by the established sociological canon, namely with three assets broadly approximating to class, status and party (see Marshall, et al. 1988, and Scott 1996 on the continued significance of these axes). This has led to the 'recycling of old wine in new bottles', in which only the established, sociological orthodoxies of class, status and power (reworked as some version of property, skill/ culture and organisation) become defined as assets of class inequality. It is notable that Wright and Roemer have both retreated from their earlier formulations by restricting their scope to processes linked to the labour process in some form.

This is a means of reasserting the conventional Marxist emphasis on labour (defined as employment) as fundamental to exploitation whilst not using the labour theory of value. For Roemer (1988:5), 'a class is a group of people who all relate to the labour process in the same way'. ${ }^{4}$ Wright (2000: 1563) similarly sees one facet of exploitation as the 'exclusion of the exploiters [it should be: exploited: note - J. T.] from access to certain productive resources', and the ability of the exploiters 'to appropriate the labour effort of the exploited'. The problem here is that without a definition as to what constitutes 'productive' and 'labour', this definition still potentially allows the proliferation of axes of exploitation.

In practice, however, Wright draws upon a reductive account of what production and labour entails, for instance in his observation (Wright 1997:23) that 'experts like managers, occupy a privileged appropriation location within exploitation relations'. Ultimately, then, this approach leads us back to the 'employment aggregate approach', which assumes, rather than demonstrates, the importance of the formal division of labour as the bedrock of class and inequality. The promise [...] to offer a robust alternative to the labour theory of value as a theory of exploitation has not been redeemed. (Savage et al 2005)

\section{CONCLUSION}

An analysis of Wright's theoretical views has turned out to be productive in that it has allowed us to interrogate several issues whose significance for not only sociology but also other social sciences cannot be over-estimated. This refers not merely to the issue of class identification central in Wright's theory, but also to the treatment of ownership, the

\footnotetext{
${ }^{3}$ Such an expression is found in original, although, of course, in Pandora's myth the content of the can was completely different.

${ }^{4}$ This is surely not sufficient, as, without specifying further the kind of labour one is dealing with, and, in genral, class determination solely on the basis of the division of labour in isolation from economic property relations is bound to bring unsatisfactory results.
} 
distinction between social classes and strata as well as some important epistemological questions. Given those outcomes of the paper, relatively less, albeit by no means not, important, considering the popularity of Wright's approach to class, are the weak points and flaws whose presence in Wright's theoretical framework has been disclosed.

\section{References}

[1] Burris Val (1980). Class Formation and Transformation in Advanced Capitalist Societies: A Comparative Analysis. Social Praxis, 7: 147-179.

[2] Carchedi G. (1977). The Economic Identification of Social Classes. London: Routledge \& Kegan Paul.

[3] Collins Randall (1979). The Credential Society. New York: Academic Press.

[4] Levine Andrew, Erik Olin Wright (1980). "Rationality and Class Struggle." NewLeft Review 123.

[5] Miller D. (1996). London Review of Books, October 31.

[6] Mises 1. (1936). Socialism: An Economic and Sociological Analysis, London: Jonathan Cape.

[7] Parkin Frank (1979). Marxism and Class Theory: A Bourgeois Critique. New York: Columbia University Press.

[8] Poulantzas Nicos (1975). Classes in Contemporary Capitalism. London: New Left Books.

[9] Poulantzas N. (1973a). On social classes. New Left Review, 78; 27-54.

[10] Poulantzas N. (1973b). Political power and social class. London: New Left Books.

[11] Przeworski Adam (1977). "Proletariat into a Class: The Process of Class Formation from Karl Kautsky's The Class Struggle to Recent Controversies." Politics and Society 7:343-401.

[12] Reich Michael (1981). Racial Inequality: A Political-Economic Analysis. Princeton: Princeton University Press.

[13] Roemer John (1982). A General Theory of Exploitation and Class. Cambridge, Mass.: Harvard University Press.

[14] Savage M., Warde A., Devine F. (2005). Capitals, assests and resources: some critical issues, British Journal of Sociology, 56(1); 31-47.

[15] Sorensen A. (2000b). Towards a Sounder Basis for Class Analysis, American Journal of Sociology, 105(6); 1523-1558.

[16] Van Parijs Philippe (1982). Functionalist Marxism Rehabilitated. Theory and Society, $11 ; 497-511$.

[17] Weber M. (1947). The Theory of Social and Economic Organization; being Part I of Wirtschaft und Gesellschaft, translated from the German by A. R. Henderson and Talcott Parsons, London: W. Hodge.

[18] Wright Erik Olin (1978a). Class, Crisis, and the State. London: New Left Books. 
[19] Wright Erik Olin (1978b). Race, Class, and Income Inequality. American Journal of Sociology, 83; 1368-1397.

[20] Wright Erik Olin (1983). Giddens's Critique of Marxism. New Left Review, 138; 11-35.

[21] Wright Erik Olin (1985). Classes. London: New Left Books.

[22] Wright Erik Olin, Luca Perrone (1977). Marxist Class Categories and Income Inequality. American Sociological Review, 42; 32-55.

( Received 13 June 2014; accepted 22 June 2014 ) 